\title{
Funksjonell MR kan gi ny kunnskap om autisme
}

\section{Barn med autisme har endret respons i hjernen når de skal takle noe uventet. Det viser foreløpige resultater fra ny norsk studie.}

Autisme er en vanskelig sykdom å studere, fordi barn med denne diagnosen har svært ulik funksjon og symptompresentasjon.

Vi rekrutterer gutter i alderen 6-13 år med diagnosen autisme i Bergen og omegn. Studien startet i 2011 og vil fortsette til man har et tilstrekkelig pasientutvalg. Det gjøres MRundersøkelse der omfattende kartlegging av hjernens struktur og funksjon inngår. Studien er et samarbeid mellom fMRI-gruppen i Bergen og radiologisk avdeling ved Haukeland universitetssykehus. Foreløpige data, basert på et foredrag ved konferanse om autisme ved Karolinska Institutet tidligere $i$ år, er presentert $i$ en ny artikkel, der bakgrunnen for studien og metodene presenteres (1).
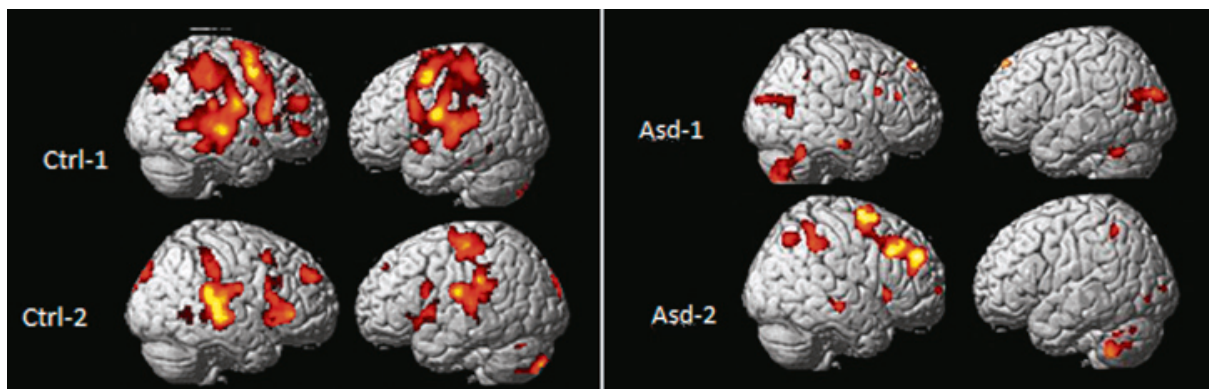

Bildet viser lokalisering i hjernen av fMRI-respons hos to friske barn (Cntrl-1, Cntrl-2) og to barn med autismediagnose (Asd-1, Asd-2) (1). Gjengitt med tillatelse fra Microbial Ecology in Health and Disease

Med fMRI-undersøkelse skal vi studere hjerneforandringer som er assosiert med barnas motstand mot uforutsette endringer og dermed det nevrobiologiske grunnlaget for et slikt symptom. Hypotesen er at barn med autisme reagerer annerledes på uventede hendelser enn barn som ikke har autisme, og at dette kan ses ved et funksjonelt MR-opptak. Barna får en lytteoppgave med uventede hendelser.

Så langt har vi få pasienter. Det er for tidlig å konkludere, men det virker å være en tendens til støtte til hypotesen vår om at barn med autisme har endringer $i$ både nevronal aktivitet ved fMRI og synaptisk aktivitet målt ved MR-spektroskopi sammenliknet med friske kontrollbarn.

\section{Mona K. Beyer}

monbey@ous-hf.no

Avdeling for radiologi og nukleærmedisin Oslo universitetssykehus, Rikshospitalet

\section{Litteratur}

1. Hugdahl K, Beyer MK, Brix M et al. Autism spectrum disorder, functional MRI and MR spectroscopy: possibilities and challenges. Microb Ecol Health Dis 2012; 23: 18960.

\section{Hjerneslagpasienter kommer for sent til behandling}

\section{Altfor mange pasienter med akutt \\ hjerneslag kommer for sent til \\ sykehus og intravenøs trombo- \\ lytisk behandling.}

Ved et stort hjerneinfarkt forsvinner 1,7 millioner nevroner per minutt. Derfor er det viktig at intravenøs trombolytisk behandling påbegynnes så raskt som mulig. Dessverre får kun en liten andel av pasientene slik behandling raskt nok. Prehospital forsinkelse, dvs. forsinket ankomst til akuttmottaket, er den viktigste årsaken til at så få får trombolytisk behandling.

Vi har gjennomført en prospektiv studie hvor 440 pasienter med hjerneinfarkt, intracerebral blødning og TIA ble inkludert (1). Tid fra symptomdebut til ankomst til akuttmottaket ble registrert og faktorer relatert til prehospital forsinkelse analysert.
Median tid fra symptomdebut til innleggelse var tre timer, hvorav omtrent halvparten var tiden fra symptomdebut til første medisinske kontakt (AMK-sentral, legevakt, fastlege eller direkte oppmøte i akuttmottak). Rundt $12 \%$ av pasientene ankom akuttmottaket etter 24 timer.

Multivariat lineær regresjonsanalyse viste at uttalte symptomer/utfall, bruk av ambulanse og lav alder var relatert til rask innleggelse. Det var ingen signifikant sammenheng mellom prehospital forsinkelse og kjønn, utdanningsnivå, tidligere cerebrovaskulær hendelse, tidligere hjertesykdom eller typiske risikofaktorer for hjerte- og karsykdom.

Resultatene kan tyde på at folk har lite kunnskap om hjerneslag og om nødvendigheten av rask behandling. At pasienter som tidligere hadde vært innlagt med hjerneslag eller TIA ikke kommer tidligere enn andre, kan tyde på at helsepersonell ikke informerer godt nok om risikofaktorer og sympto- mer ved hjerneslag og at tid er av avgjørende betydning for utfallet. Pasienter med mistenkt hjerneslag bør ringe 113 så raskt som mulig og bringes direkte til sykehus. Kunnskap om hjerneslag og hjerneslagbehandling hos helsepersonell og i befolkningen bør bedres.

\section{Kashif Waqar Faiz \\ kashif.faiz@medisin.uio.no \\ Nevroklinikken \\ Akershus universitetssykehus \\ og \\ Institutt for klinisk medisin \\ Universitetet i Oslo}

\section{Litteratur}

1. Faiz KW Sundseth A Thommessen B et al. Prehospital delay in acute stroke and TIA. Emerg Med J 2012. E-publisert 14.8 